Ars Gratia Cultus: Ovid as Beautician

Author(s): Peter Green

Source: The American Journal of Philology, Vol. 100, No. 3 (Autumn, 1979), pp. 381-392

Published by: The Johns Hopkins University Press

Stable URL: http://www.jstor.org/stable/293934

Accessed: 11-05-2015 20:54 UTC

Your use of the JSTOR archive indicates your acceptance of the Terms \& Conditions of Use, available at http://www.jstor.org/page/ info/about/policies/terms.jsp

JSTOR is a not-for-profit service that helps scholars, researchers, and students discover, use, and build upon a wide range of content in a trusted digital archive. We use information technology and tools to increase productivity and facilitate new forms of scholarship. For more information about JSTOR, please contact support@jstor.org. 


\section{ARS GRATIA CULTUS: OVID AS BEAUTICIAN}

\section{The surviving fragments of Ovid's Medicamina Faciei}

Femineae have received scant attention from editors and commentators. Their interest, such as it is, has been predominantly textual. ${ }^{1}$ No one has thought of investigating the five recipes for face packs, to improve the complexion or remove various skin defects, which take up the whole of the second fragment (lines 51-100). ${ }^{2}$ The clear implication is that they are, by definition, not worth any scholar's serious attention. Like ancient board games, another remarkably neglected topic, ${ }^{3}$ they are ignored as frivolous-and, therefore, it is assumed, unimportant. This attitude may well have been reinforced by the undoubted fact that, in general, our ancient sources for medical or pharmacological prescriptions are riddled with old wives' tales and outré, if not downright disgusting, materials. Here the Elder Pliny's Natural History ${ }^{4}$ is one of the worst

${ }^{1}$ See, e.g., A. Kunz, P. Ovidii Nasonis Libellus de Medicamine Faciei, Vienna 1881 (hereafter 'Kunz'), and F. W. Lenz, Heilmittel gegen die Liebe: Die Pflege des weiblichen Gesichtes, Berlin 1960 (hereafter 'Lenz'). Both print somewhat perfunctory exegetical notes, which make only the slightest of attempts to come to grips with the subject matter under discussion.

${ }^{2}$ This omission extends even to R. J. Forbes's essay on 'Cosmetics and Perfumes in Antiquity,' which forms ch. 1 (pp. 1-50) of his Studies in Ancient Technology, vol. 3, 2nd ed., Leiden 1965, and is, by and large, one of his less satisfactory investigations.

${ }^{3}$ The lack of modern scholarship on both Greek and Roman board games is remarkable when one considers the evidence, both literary and archaeological, which is available-but no more remarkable than the wild theories that flourish unchecked in such authorities as do exist. See, e.g., L. Becq de Fouquières, Les Jeux des Anciens, 2nd ed., Paris 1873: H. Lamer, 'Lusoria Tabula,' PWK vol. 13 (1926) cols. 1900-2029 (in particular cols. 1988 and 2008ff., on the wholly imaginary '36-Felderspiel'); and S. G. Owen's edition of Ovid's Tristia, bk. 2 (Oxford 1924) 252ff. There is little that is reliable to consult except for two sensible and unpretentious articles by R. G. Austin, 'Roman Board Games' (I) and (II), in Greece and Rome 4 (1934) 24-34; ibid. (1935) 76-82. Cf. also J.P.V.D. Balsdon, Life and Leisure in Ancient Rome (London 1969) 154-59.

${ }^{4}$ See, e.g., $H N 28.30,183-88,233 ; 30.108,113-18,120-21$. Not all the recipes recorded by Pliny fall into this category; but he seems quite incapable of distinguishing between the functional and the spurious, between scientifically based prescriptions and those dictated by the analogies of sympathetic magic. 
offenders. Can the formulae presented by Ovid be likewise dismissed as a mere literary rehash of stale superstitions? It is the purpose of this paper to analyse the materials involved; to deduce, from comparison with our other surviving sources, what effect the ingredients were believed to have; and to estimate, with the aid of modern chemical and dermatological knowledge, what effect they in fact did have. The results shed a most interesting light on Ovid's attitude to women, to the didactic function, and to his chosen role as praeceptor amoris.

His first recipe (53-66) is for a face pack guaranteed to produce a bright complexion (68). The ingredients mentioned are: barley, vetch, 'Tuscan spelt' (probably emmer), eggs, honey, hartshorn, narcissus bulbs, and gum. Barley appears in a skin-cleansing preparation as early as the 16 th cent. B.C. ${ }^{5}$ Pliny mentions both barley and vetch as ingredients in face packs. ${ }^{6}$ They are also specifically credited with the ability to cleanse the complexion and remove pimples. ${ }^{7}$ The same is true of hartshorn, or powdered stag-antler. ${ }^{8}$ Though 'Tuscan spelt' is not mentioned elsewhere in our classical sources, two early Egyptian recipes for the removal of wrinkles mention 'germinated spelt' ( $b d t)$ as an ingredient, ${ }^{9}$ and this may well be what Ovid means. Pliny claims ( $H N 21.129)$ that the narcissus, when mixed with meal, 'cleans wounds and removes black psoriasis.' Gum, probably gum arabic, is credited with removing wrinkles and improving the complexion. ${ }^{10}$ Honey was regarded in antiquity as a general emollient, ${ }^{11}$ and thought to cure spots. ${ }^{12}$ Eggs were treated as a kind of heal-all, in particular for bruises, itches and skin irritation, and sunburn. ${ }^{13}$ Powdered ostrich egg figured in one Egyptian face pack. ${ }^{14}$

We see, then, that our ancient sources, with some unanimity, regarded the ingredients of this recipe as effective skin

${ }^{5}$ Pap. Ebers $\$ 87$, cited by Forbes, p. 16. Its date is the early 16 th cent.

${ }^{6} H N 20.20$.

${ }^{7}$ Plin. $H N$ 22.122, 151, 161; 24.63; 28.183; 30.75; Celsus 2.33.5, 5.16.

${ }^{8}$ Plin. $H N$ 28.187, 233, 241.

${ }^{9}$ Pap. Ebers ibid. Cf. Forbes pp. 16-17.

${ }^{10}$ Plin. $H N$ 24.106; Pap. Ebers ibid.

11 Plin. $H N$ 22.107-9.

${ }^{12}$ Plin. $H N$ 30.29, 73; Celsus 5.16; it also appears in several early Egyptian skin-treatment formulae (e.g., Pap. Edwin Smith \$21.3-8, cf. Forbes p. 16).

${ }^{13}$ Plin. $H N$ 29.39ff., esp. $\$ \S 44,47$; cf. 28.66.

${ }^{14}$ Pap. Ebers $u t$ supr. 
cleansers. How effective in fact would it have been for its professed purpose, when judged by modern scientific criteria? ${ }^{15}$ Though barley is not used in modern preparations, oat-flour and oatmeal, which belong to the same family (Gramineae), form a staple ingredient of contemporary face packs, creams, soaps and lotions. ${ }^{16}$ Meal of this type contains starch, lipids, proteins, and small quantities of saponine, all of which help to moisturise and oil the skin as well as keeping it smooth and fair. ${ }^{17}$ Dermatologists prescribe preparations containing oatmeal to alleviate itching and psoriasis; the grain also contains vitamins $\mathrm{A}, \mathrm{B}, \mathrm{D}$, and $\mathrm{E}$, especially in the germs. ${ }^{18}$ For this reason wheat-germ is used in modern beauty masks, ${ }^{19}$ and we need not doubt that the employment of germinated spelt in antiquity ${ }^{20}$ had a similar purpose, even if it was not fully understood. Eggs are regularly used in modern cosmetic preparations. Winter ${ }^{21}$ gives the recipe for an egg white face mask that also contains wheat-flour, milk, and honey. Egg white applied facially forms an adhesive film that shrinks as it dries, tightens the skin, reduces pores, and makes the texture of the skin finer. This astringent action also stimu-

${ }^{15}$ In all that follows I am deeply indebted to the expert advice and guidance of M. Andrzej and Mme Halina Pradzynski. M. Pradzynski, a professional chemist, advised me on the properties of the various substances involved, while his wife, the head of a skin-care clinic in Austin, Texas, was able not only to describe the processes of modern cosmetology for me, but also to estimate the practical effectiveness of each ancient formula in modern terms. Without their constant help-and the literature on the subject to which they referred me-this paper could hardly have been begun, much less completed.

${ }^{16} \mathrm{~F}$. Winter, Handbuch der gesamten Parfumerie und Kosmetik (Vienna 1959) 501, 508; cf. J. Coe and A. Juliano, 'A new natural ingredient for cosmetic formulators,' Drug and Cosmetic Industry 113 (1973) 48; D. Chase, The Medically Based No-Nonsense Beauty Book (New York 1974) 273.

${ }^{17}$ Personal communication, Mme Halina Pradzynski. Another modern staple is almond paste, to which we may compare the use in antiquity of fenugreek: cf. Pap. Edwin Smith \$\$21.9, 22.7-10 (= Forbes pp. 15-16), and Plin, $H N$ 22.125; 24.184-87.

${ }^{18}$ Cf. J. P. Braeken, Vitamins in Cosmetology (Basle 1971), passim.

19 'It is marketed for this purpose in Germany (Firma Keimdiet) and the USA. There is a belief among skin-care specialists that "what is good for the body from inside is also good from outside," i.e. for the skin' (personal communication, Mme Pradzynski).

${ }^{20}$ Med.Fac. 65; cf. above, n. 9.

${ }^{21}$ Op. cit. p. 509. 
lates blood circulation, which, in turn, imparts a healthy glow to the complexion. ${ }^{22}$ Egg yolk contains lecitin and cholesterol, both excellent emulsifiers and emollients, and is widely used for this purpose in modern creams and lotions. ${ }^{23} \mathrm{Gum}$ and honey not only reinforce the effect of egg white, but were clearly used in antiquity as binders (Med.Fac. 81-83) to hold other ingredients in a paste. Though vetch is not employed today, a closely related member of the leguminosae, alfalfa (Medicago sativa), figures in some preparations. Its leaves contain saponines, karoten, vitamin C, and several enzymes. ${ }^{24}$ The juice of the narcissus bulb is, likewise, an emollient 'which reduced the pain of erodents and discutients and was therefore mixed with them. ${ }^{25}$ The hartshorn (cornu cervinum) was probably burnt: its ash $^{26}$ contains quicklime (calcium oxide), with phosphates and carbonates, including ammonium carbonate. Thus it would have acted as a stimulant, cleanser, and abrasive: all modern cosmetic functions. ${ }^{27}$ Such a preparation, in the opinion of a distinguished skin-care specialist, ${ }^{28}$ would be 'highly effective for smoothing the skin and giving it a younger, radiant look.'

The second formula (69-76) is not a face pack, but a cleansing aid designed for general application to the body (81). Unlike the previous recipe, it contains mineral ingredients. Once again, every item was familiar in antiquity for its dermatological or cosmetic properties. Lupin seeds, whether as meal or in the form of an oil extract, ${ }^{29}$ were used to improve the complexion, to remove freckles, as a treatment for scabies, and in

22 Pradzynski, ut supr.

${ }^{23}$ M. G. De Navarre, The Chemistry and Manufacture of Cosmetics (Orlando, Fla. 1975) vol. 3, pp. 337-438.

${ }^{24}$ De Navarre, op. cit. vol. 3 p. 435 ; O. Gessner, Die Gift- und Arzneipflanzen von Mitteleuropa (Heidelberg 1953) 260.

${ }^{25}$ W. G. Spencer, Celsus De Medicina (3 vols., London 1935-38), vol. 2, p. xliii; cf. Celsus 5.15 and Plin. $H N$ 20.103, which recommends it with honey and 'soda' (see below, n. 36).

${ }^{26}$ Spencer, ibid. pp. xxvii-viii.

${ }^{27}$ Abrasives (e.g. pumice) are regularly used to clean and smoothe the skin. To remove the top layers of dead cells from the skin's stratum corneum not only improves its color and texture, but also 'activates the natural renewal process of skin cells' (Mme Pradzynski, ut supr.).

${ }^{28}$ Mme Pradzynski, personal communication.

${ }^{29}$ Plin. $H N 15.31$. 
poultices. ${ }^{30}$ Beans or bean-meal (lomentum) dispersed boils and vitiligo: ${ }^{31}$ lomentum was specifically used in face packs. ${ }^{32}$ White lead (cerussa or psimythion) was a popular-if highly dangerous-cosmetic ingredient throughout antiquity. ${ }^{33}$ Pliny specifically links it with improvement of the complexion, ${ }^{34}$ and with the removal of scars and facial eruptions. ${ }^{35}$ What Ovid describes (Med.Fac. 73) as nitri spuma rubentis, or 'spume of red natron,' was more commonly known as aphronitrum ('soda-foam'). The word nitrum was loosely used, in various contexts, to identify not only soda or natron, but also potash, and, on occasion, saltpetre. ${ }^{36}$ There is no doubt, however, as to the nature of aphronitrum. It was what is now known as soda-scum, that is, "carbonates and nitrates of soda and potash coloured by copper and iron oxides. ${ }^{37}$ This accounts for the red or purple colour, noted not only by Ovid (Med.Fac. 73), but also by Pliny. ${ }^{38}$ The use of this natural sodium carbonatebicarbonate compound to improve the complexion dates back, again, at least as far as the 16th cent. B.C. ${ }^{39}$ Both soda and soda-scum were used by the Romans in various skin-cleansing or erodent preparations. ${ }^{40}$ Pliny several times refers to the

${ }^{30}$ Plin. $H N$ 22.154, 156; 32.87; Celsus 5.28.16B, 2.33.5.

${ }^{31}$ Plin. $H N$ 22.140, 33.85; Diosc. 2.127; Celsus 5.28.19D; cf. Kunz p. 70.

${ }^{32}$ Forbes, op. cit. pp. 40-41.

${ }^{33}$ Securely identified (from a Graeco-Egyptian Fayyum portrait) as the basic lead acetate commonly known as 'sugar of lead,' cerussa was formed (Plin. $H N$ 34.175-76, cf. Spencer, op. cit., vol. 2 p. xlviii) by pouring vinegar over lead shavings, and was sometimes confused with natural cerussite, or lead carbonate (Forbes pp. 235-36; T. L. Shear, 'Psimythion,' in Class. Stud. Pres. to E. Capps, Princeton U.P. 1936, pp. 314-17). When heated it produced the yellow and red oxides of lead.

${ }^{34} H N 34.176$.

${ }^{35} H N$ 28.139, 183; cf. Vitruv. 7.12.1; Diosc. 5.103; Celsus 5.28.15E.

${ }^{36}$ M. P. Crosland, Historical Studies in the Language of Chemistry (Cambridge, Mass., 1962) 106.

${ }^{37}$ Spencer, op. cit. vol. 2 p. lii.

${ }^{38} H N$ 31.111-13, a highly useful passage. It informs us, inter alia, that 'red natron' was imported from both Egypt and Lydia, in the latter case made up as lozenges.

${ }^{39}$ Two prescriptions in the Edwin Smith Papyrus (21.3-8) list 'red natron' as an ingredient, and Egypt was always the main source for this substance. Cf. Forbes pp. 16-17, 181-86; Spencer, vol. 2, p. lii.

${ }^{40}$ Spencer, loc. cit.; Diosc. 5.103; Celsus 5.18.7B,35; Plin. HN 20.66, $22.125 ; 31.106-22$. Soda-scum was also employed in poultices for inflamed joints or abscesses. 
cosmetic properties of aphronitrum: it was thought to remove wrinkles and freckles, improve the complexion, and clear up such complaints as ringworm, impetigo, and scabies. ${ }^{41}$ 'Soda' in its basic form had similar uses, i.e., to clean up pimples, blisters, boils and ulcers. ${ }^{42}$ Ovid's final ingredient, the iris, was recommended as a cure for skin complaints ${ }^{43}$ and as an agent for removing freckles. ${ }^{44}$

This formula, too, would have been effective. Its ingredients suggest that it was used 'as a cleansing aid combining the detergent qualities of soda, the whitening action of the lead pigment, an abrasive action by the roasted lupin and fried bean powders, and the violet scent of the iris.' 45 The root or bulb of the iris also yields orris camphor, which could serve as a calefacient and cleanser. ${ }^{46}$

Ovid's third formula (77-82) is essentially simple-one ingredient, plus honey as an emulsifying binder, and designed to remove spots or freckles. But just what was alcyoneum, and how did it operate? The most precise specifications are given by Dioscorides, ${ }^{47}$ who lists no less than five varieties. Pliny ${ }^{48}$ knows four, which correspond with four of those of Dioscorides. All are clearly substances found either in the sea or as flotsam on beaches. ${ }^{49}$ Ovid's specifications-that alcyoneum

${ }^{41}$ Plin. $H N$ 22.65, 24.63, 34.176; cf. Celsus 5.28.18, 17C, and Plin. $H N 31$. 116.

${ }^{42}$ Celsus 2.33.5, 5.28.15D; Plin. $H N$ 30.29, 31.115-16, 120 , cf. 20.53, and Kunz p. 72.

${ }^{43}$ Celsus 5.16; Plin. $H N$ 21.143, 23.63, 26.143.

${ }^{44}$ Plin. $H N$ 28.188. For the value attached to the Illyrian iris in particular see Theophr. $H P$ 9.7.4; Plin. $H N$ 13.18, 21.41.

${ }^{45}$ Personal information, Mme Pradzynski. The iris still provides the characteristic scent known today (somewhat misleadingly) as 'essence of violets.'

${ }^{46}$ Spencer, vol. 2 p. xxxvii.

47 5.118.1-4 (ed. M. Wellmann).

${ }^{48}$ HN 32.86-87.

${ }^{49}$ Combining the evidence of Pliny and Dioscorides ( $\mathrm{nn}$. 47-48 above) we arrive at the following categories: (i) a compact, heavy-textured, spongy substance, the colour of ash, found most commonly on beaches, and giving off a pungent, fishy odour. (ii) a light, porous substance, smelling like seaweed, and resembling the film or membrane which sometimes grows over the eye. (iii) a purplish or whitish object, shaped like a worm or grub, sometimes known as 'Milesian,' and characterised by Pliny as the best variety. (iv) a substance resembling fungus or rotten sponge, with an inner texture reminiscent of pumice, and known locally in the Propontis [Sea of Marmara] as 'sea-foam,' 
comes from seabirds' nests, and cures skin diseases-narrows the field down to Dioscorides' first two categories, which also correspond to Pliny's. The first is compact, spongy, ashcoloured, and most often found on beaches. The second is light, porous, and resembles that film or membrane which sometimes grows over the eye: perhaps also "wool with the grease still in it. ${ }^{\prime 50}$ Both have a pungent marine odour, like fish or seaweed. These are the varieties which, as Dioscorides says, 'are used in making women's unguents, and to cure moles, erysipelas, leprosy . . . birthmarks, and spots in general.' Pliny confirms that 'the property of alcyoneum is to clear away ulcers and to cleanse,' and that these varieties are made from seabirds' nests. Their identification presents rather more problems than does Dioscorides' type (iv) [see n. 49], which was clearly some type of coral, 'incinerated to produce quicklime and used as an exedent and for skin diseases.' ${ }^{51}$

The ancient source that we might legitimately hope would help us most, that is, Aristotle's detailed description of the halcyon's nest in his Historia Animalium, ${ }^{52}$ is in fact so confused and fanciful that it is not at all clear whether we have to do with a true nest, or some other marine phenomenon. ${ }^{53}$ However, we know that the cormorant makes its cliff-nest from piles of seaweed and guano (which would certainly account for the fishy smell), ${ }^{54}$ while the bee-eater kingfisher has young that hatch naked, and 'are covered with a waxy material derived from honey consumed by the parents, ${ }^{55}$ which splits away and is discarded when the chicks are ready to leave the nest. This wax sheath might correspond to the alcyoneum resembling the membrane that grows over the eye. If so, it might

\footnotetext{
'sea-slime,' or 'sea-down.' (v) a light and porous substance resembling 'wool with the grease still in it': this is the variety known only to Dioscorides, and may in fact be identical with (ii).

so See n. 49 ad fin.

${ }^{51}$ Spencer, vol. 2, p. xviii. We may note that the other formulae noted by Pliny in this context $(H N 32.84-85)$ include as ingredients the calcined shell of murex and cuttlefish.

${ }^{52}$ HA 616A 19ff., cf. Plut. De soll. an. 35, De am. pr. 494A; Aelian NA 9.17.

${ }^{53}$ J. Pollard, Birds in Greek Life and Myth (London 1977) 13, 96-97.

${ }^{54}$ Enc. Brit. (1965 ed.) vol. 6, p. 502.

${ }^{55}$ Van Nostrand's Scientific Encyclopedia s.v. 'Kingfishers and other Coraciforms': I owe this reference to M. Andrzej Pradzynski.
} 
well have acted as an emollient. On the evidence it is impossible to identify Ovid's alcyoneum with assurance. But if it was made from some kind of bird's nest, it might indeed have possessed efficacious properties as a facial cleanser. Some birds use their saliva as a binding agent, ${ }^{56}$ and saliva "contains, besides mucus, proteolytic and other enzymes that may help in removing the top layer of dead cells from the skin.' ${ }^{57}$ There was a belief in antiquity that 'good ointment should be made with human spittle and hence certain cosmetics were chewed by slaves before application. ${ }^{\prime}{ }^{58}$ More important, such birds more often than not made their nests of clay, which at once suggests the presence of kaolin. Kaolin is regularly used in modern face masks 'to cleanse skin by absorption of sebum and impurities, to soothe irritations and remove redness. ${ }^{59}$ It was also used in antiquity for the same purpose: Dioscorides (5.155) recommends masks made with Chian or Selinan clay, which contains a very high proportion of kaolin. ${ }^{60}$ Thus there is a good chance that Ovid's formula worked along similar lines.

The fourth formula (83-98) is for another face pack, but one of a different type from those previously mentioned. The ingredients include frankincense and myrrh, natron (or perhaps saltpetre: see below, n. 67), gum, honey, fennel, ammoniac salt, dried rose leaves, and barley water. Frankincense was traditionally used in preparations designed to cleanse the complexion, and to remove blemishes or wrinkles. ${ }^{61}$ Myrrh was similarly prescribed as a cleanser, and to fade scars. ${ }^{62} \mathrm{Gum}$ and

${ }^{56}$ Most notably certain varieties of swallow (Chaetura pelagica) and swift (Collocalia), which build the so-called 'edible nest' from which the Chinese make soup.

${ }^{57}$ Personal communication, Mme Pradzynski. She adds, however, that 'in order to achieve this effect the preparation should be activated with water, which is not mentioned in Ovid's text.' This is not, of course, to imply that enzymes in modern cosmetological usage are produced by anything resembling the ancient methods!

${ }^{58}$ Forbes, p. 41.

${ }^{59}$ Pradzynski, ut supr.

${ }^{60}$ Forbes, ibid., cf. Winter, op. cit. p. 508, and E. Sagarin, Cosmetic Science and Technology (New York 1974) 308-10.

${ }^{61}$ Pap. Ebers $\$ 87$ (= Forbes p. 17); Theophr. HP 9.4.4-9; Celsus 5.56; Diosc. 1.81; Plin. $H N$ 12.51-65 passim; 13.126; 30.75, 116; 32.106.

${ }^{62}$ Celsus 5.5-6, 16; Plin. $H N$ 24.86; 28.214, 245; 30.116. 
honey we have already studied: ${ }^{63}$ gum was also credited with astringent powers. ${ }^{64}$ Fennel was a popular application for open wounds. ${ }^{65}$ At line 85 Kenney's reading, rodenti corpora nitro, would indicate, as before, sodium carbonate, with its erodent and cleansing properties. ${ }^{66}$ But an alternative reading is radenti tubera nitro, and this would indicate a substance capable of removing warts: in all likelihood saltpetre, ${ }^{67}$ for which the word nitrum was sometimes used. 'Ammoniac salt,' from the Libyan desert, was prescribed as a styptic and cleansing agent, to draw out abscesses, and to improve the complexion. ${ }^{68}$ Rose leaves were employed for cosmetic purposes, including face masks, ${ }^{69}$ and barley water was a popular medical standby. ${ }^{70}$

Again, this formula possesses proven qualities for aiding the complexion. The main active ingredients are aromatic oils, contained in the resins of myrrh and frankincense. Apart from their fragrance, some of these oils have bacteriocidal properties, ${ }^{71}$ serve as cosmetic preservatives, and, most important, 'stimulate blood circulation in ageing, dull skin, imparting to it a healthy, pink color.' 72 It is indicative of his practical, professional interest that Ovid, like modern skin specialists, was well

${ }^{63}$ See above, nn. 10-12.

64 Plin. $H N$ 24.106.

${ }^{65}$ E.g. dog-bites: Diosc. 3.70.1.

${ }^{66} \mathrm{Cf}$. above, nn. 36-40.

${ }^{67}$ That is, sodium or potassium nitrate. As stated earlier (p. 387), writers in antiquity never clearly distinguished between soda (natron), potash, and-to a lesser degree-saltpetre. See, e.g., Theophr. HP 3.7.6, and Varro RR 1.7.8 (also Forbes pp. 181ff., esp. 186-88). The nitrates of sodium or potassium would be effective, up to a point, against warts, whereas sodium carbonate would not (personal information, M. Andrzej Pradzynski). Since, however, the latter possesses other medical properties applicable to the complexion (see above, p. 387, and nn. 39-40), this fact cannot be used as an argument to settle the reading of line 85 .

${ }^{68}$ Diosc. 5.109.2; Celsus 5.18.2, 19.4; Plin. $H N$ 31.105, cf. 78-79.

${ }^{69}$ Diosc. 1.43.4, 130; Celsus 2.33.1: Plin. $H N$ 21.123, 125.

${ }^{70}$ Hippocr. de morb. mul. p. $853 \mathrm{Kühn,} \mathrm{cf.} \mathrm{Kunz} \mathrm{p.} \mathrm{77,} \mathrm{and,} \mathrm{for} \mathrm{other}$ recipes involving barley, above, $\mathrm{nn}$. 5-7.

${ }^{71}$ G. Urdang, 'Pharmacy in Ancient Greece and Rome,' in Ernest Guenther, The Essential Oils, vol. 1 (New York 1948) 3.

${ }^{72}$ Personal communication, Mme Halina Pradzynski. For a general survey of the curative properties inherent in the aromatic oils see R. Gattefosse, Aromathérapie (Paris 1937), cf. De Navarre, op. cit., vol. 3, p. 87. 
aware (see line 97) that such a face pack could not be kept on for long, the reason being that after a while stimulation would turn to irritation. Gum, honey and barley water would form a soothing lotion; fennel is listed as an ingredient in modern herbal masks, especially as an antidote to acne. ${ }^{73}$ Until recent years nitric acid and silver nitrate were used with good effect against warts. ${ }^{74}$ Ammoniac salt-that is, not modern sal ammoniac, but sodium chloride 'rendered hygroscopic by the inclusion of calcium and magnesium chloride' 75 - would have been an effective agent for drawing out inflammation or maturing boils. Rose leaves are still used in face masks today.

The final, incomplete formula (99-100) is equally therapeutic. Pliny was aware of the poppy's qualities, in particular as a cure for skin eruptions, and as a facial fomentation. ${ }^{76}$ Its skin-cleansing properties are also referred to by Celsus, Dioscorides, and Galen. ${ }^{77}$ Cold water and rubbing are highly beneficial for the complexion, producing a healthy glow-one excellent reason for reading multus rather than nullus in line $98^{78}$ - while poppy seeds contain a high concentration of oil rich in polyunsaturated fatty acids, including linolenic acid. ${ }^{79}$ It has been shown ${ }^{80}$ that certain essential fatty acids in poppy seeds, especially some isomers of linolenic acid, are effective against eczema, dry skin, and scalp diseases.

It is impossible to conclude one's investigation of these prescriptions without feeling considerable admiration for Ovid's practical judgment and discrimination. Just how perversely fantastic such formulas could be-and how credulous the literary mind that collected them-we know from Pliny. The old polymath devotes one section of his Natural History to facial

${ }^{73}$ L. Dainov, in Soap, Perfumery and Cosmetics, vol. 36 (1963) 702.

${ }^{74}$ Personal information, M. Andrzej Pradzynski.

${ }^{75}$ Spencer vol. 2, p. lii; cf. W. H. S. Jones's note to Plin. $H N 31.79$ in vol. viii of the Loeb edition.

${ }^{76}$ HN 20.198-209, esp. $\$ \$ 201-2$.

${ }^{77}$ Celsus 2.32; Diosc. 4.64.2, 65.2; Galen, Simpl.Medic. 7.12.13, cf. Kunz op.cit. p. 78.

${ }^{78}$ For other arguments pointing in the same direction see G. P. Goold, 'Amatoria Critica,' HSCPh 69 (1965) 59.

${ }^{79}$ Personal information, Mme Halina Pradzynski.

80 J. S. Jellinek, Formulation and Function of Cosmetics (New York 1970) 377, who also cites J. Shepherd in Drug and Cosmetic Industry, vol. 38 (1936) 3. 
remedies and skin cures. ${ }^{81}$ Among other substances he recommends for this purpose are mouse dung, macerated ants, vulture's blood, and 'legs of locusts beaten up with he-goat suet.' Elsewhere ${ }^{82}$ he similarly recommends bull's dung, and a formula involving ass's urine taken at the rising of the Dog Star. He also states, as though it were the result of personal experiment: 'I find (invenio) that a heavy cold clears up if the sufferer kisses a mule's muzzle.' ${ }^{83}$ Ovid will have no truck with this kind of hocus-pocus, ${ }^{84}$ and the implications are highly interesting. It is Pliny, not Ovid, who is revealed as the literary scholar incapable of looking beyond-or indeed of evaluating-his sources. At the beginning of the Ars Amatoria (1.29) Ovid was to write: Usus opus mouet hoc, uati parete perito ('This work is based on experience: what I write, believe me, I have practised'). The Med.Fac. upholds this claim in a highly practical way. The praeceptor amoris is well acquainted with the technicalities of the beauty-parlor-a familiarity that dates back to the period of the Amores. Ovid's anguish over Corinna's maltreatment of her hair ${ }^{85}$ clearly stems from a very modern knowledge of the damage that could be done by a harsh lye bleach. ${ }^{86}$ Our attitude to his didactic pose must be

${ }^{81} H N$ 30.28-30; cf. above, n. 4.

${ }^{82} H N$ 28.185-86.

${ }^{83} H N 30.31$.

${ }^{84}$ Pliny's own claim $(H N 30.33)$ that Ovid was his source for an inscription against quinsy including goose-gall, owls' brains, and ashes of burnt swallow is intrinsically implausible: it does not figure anywhere in the surviving works (which account for the greater part of Ovid's output), and clearly does not belong in the Med.Fac. Indeed, it is hard to imagine in which lost work it could have found a place. The Medea, perhaps, as part of the eponymous heroine's pharmacopoea magica? Hardly, when we recall that this was a tragedy which earnt the praises of both Quintilian (Inst. Orat. 10.1.98) and Tacitus (Dial. 12). Nor it is easy to see how it could have been worked into a Gigantomachia (cf. $A m$. 2.2.11-16), a poem on Tiberius's victories in Pannonia (EP 3.4, cf. 2.5.27), the poem in Getic (EP 13.19ff., cf. Tr. 3.14.48), or the other commemorative minor verses listed by Owen at the end of his OCT text of the Tristia and Epp.ex Ponto.

${ }^{85} \mathrm{Am}$. 1.14, passim. Ovid was clearly obsessed by women's hair: cf. the references in $A m .1 .7$ (with which compare $A A$ 1.170), 1.11.1, 2.7.23-24, 2.8.1, 3.2.75-76. Long windswept tresses attract him ( $A A$ 1.529-30), and the one feature he always notices in Apelles' Aphrodite Anadyomene is the way in which the goddess is wringing out her wet hair $(A m$. 1.14.33-34; $A A$ 3.223-24, 401-2; $T r$. 2.526-27; EP 4.1.29).

${ }^{86}$ No clear distinction was made by ancient writers on this topic between 
reconsidered in the light of this expert knowledge. Why should a mere literary jeu d'esprit practise such cosmetic discrimination? And-a corollary that should give us much food for thought-if the Med.Fac. was intended as serious practical advice, is it not possible that we have, similarly, underestimated the practical purpose of The Art of Love? The two causes of Ovid's exile, carmen et error, the poem and the blunder, ${ }^{87}$ may, after all, be more closely linked than it is nowadays fashionable to assume. ${ }^{88}$

The University of TeXas at Austin

Peter Green

dyeing and bleaching: for some characteristic references see, e.g., Servius on Aen. 4.698, citing Cato; Val. Max. 2.1.5; Tib. 1.8.41-46; Prop. 2.18B.23-28; Ovid AA 3.163-64; Mart. 3.43, 4.36, 8.33.20, 14.26 (cf. Lucian, Amor. 40). The most common colour produced was a reddish or auburn tint, which again suggests bleaching, since the process affects dark Mediterranean hair in exactly this way rather than turning it true blonde. Confirmation comes from Pliny ( $H N$ 28.191), who describes what is clearly a lye bleach made from goat fat and beechwood ash, used by Germans to redden their hair; with typical vagueness he describes it as a soap. In addition to wood ash, such common minerals as rock alum, quicklime, or crude soda could be used to produce a caustic alkaline solution that would bleach with reddish gold shades-and could have a devastating effect on hair if used incautiously or to excess. Cf. the Encyclopedia of Technical Chemistry (New York 1954) vol. 14, p. 184.

${ }^{87} \mathrm{Tr} .2 .207$.

${ }^{88}$ This paper was originally delivered at the 1977 Annual Meeting of the American Philological Association in Atlanta, Ga. 